\title{
Designed to Disembowel
}

\section{ASHLEY GOLDBERG}

MY THIRD YEAR in Canberra, I hit a kangaroo with my car. There's a lean stretch of highway that connects the inner southern suburbs to the Tuggeranong Valley. It doesn't have any reflectors or streetlights, so that in the peak of winter-when the sun's dipping beneath the Brindabellas at five o'clock-high beams are your only means of cutting through the thick night, only way you can see the road sign that reads SLOW DOWN HIGH ACCIDENT ZONE.

My girlfriend at the time-Tegan — was from the New South Wales coast. A small beach town where the salt-water coarsened her blonde hair and the sun freckled her skin. She stood nearly as tall as me on bronze flamingo legs. We met at a party. I'd never imagined that the kind of girl who could incite whiplash when she entered a room would be attracted to me, but there was an ease to our conversation and banter that would normally suggest familiarity.

'Have you tried the punch?' she asked.

I turned to her, my mouth a circle of shock. 'Was that a threat?'

Her eyes bulged. 'No but this is. Try the fucking punch or else.'

'Or else what?'

She held a fist up to my face. 'Or else you'll get to meet Judy here.'

'Judy?' I laughed. 'What kind of name is that for a fist?' 
She dropped her hand and smiled. 'Punch and Judy. You know, the puppets. I thought it was funny.'

I smiled. 'So, who's Judy attached to?'

'Tegan.' She smiled back and walked over to the punch bowl. 'Would you like a cup?'

'I'd love one,' I said.

When the host turned the music down and began to usher us out, I held out my hand for hers to shake and she slammed her phone into my empty palm. 'That better have been what you wanted.'

I fell in love with how bold and unabashedly crass she was. She had a tendency to punctuate her sentences with a throaty cackle that reverberated about my head for days. Her ex-boyfriend was a Navy SEAL, the one before that an Olympic rower, and I was a wiry seventy kilo Jew with a penchant for sarcasm and self-deprecation.

But unfortunately, I let the pervasive inadequacy I felt beside her fester, until it began to dominate everything we did together, and likely_I imagine—overwhelm any sense she had of the guy she enjoyed spending time with at that party.

'Why do I constantly have to justify myself to you?' she'd say. 'Why can't you just believe that you're enough?'

'Because,' I'd say, 'look at you-ancient civilizations would have worshipped you.'

'I don't want worship.'

'I'll tear down the statues then.'

And then one evening after a homemade curry and a couple glasses of wine, during our ever-less frequent sex, Tegan recoiled from me like broken elastic. I thought I must have hurt her without meaning to.

'Are you okay?' I asked. 'Was I grabbing you too hard?' She didn't say anything-just tugged at the bedsheet till I lifted myself up so that she could cocoon herself in it.

After a couple of minutes of pestering her with what's-wrongs and was-it-something-I-dids, she finally spoke. 'I don't love you,' she said. 'I think I've suspected it for a while but now I know.'

My head felt murky and my body flushed with heat. 'What?'

'I wasn't thinking about you. I was thinking about my ex.' 
My mouth was dry and my tongue felt thick and heavy. I scrambled for something to refute what she was saying.

'I didn't want you to touch me tonight. I don't think I've wanted you to touch me for a long time,' she said. 'I'm sorry.' And then she began to cry.

I felt an urge to reach out and comfort her but I didn't. I sat up, swung my legs over the side of the bed and grabbed my jeans from the floor. I didn't turn to look at her, though I wanted to. Her sobbing ebbed as I walked away and stopped with the click of the front door.

I drove south, no destination in mind, just south. I wrung the wheel, grit my teeth and screamed into the night till my throat felt raw and my voice cut out like a stalled engine. Periodically I let the car drift across empty lanes, realigning the tyres before the guardrail neared. I slammed the accelerator to the floor. Suburbs named after prime ministers shot by-Barton, Deakin, Lyons. Houses thinned into bushland. Street lighting receded. A sudden chill caused me to shiver. I switched on my high beams. As the road curved, the lights of an oncoming car shined bright. I dimmed my own while they passed and lost myself in a replay of what Tegan had said.

'I don't think I've wanted you to touch me for a long time.'

'I don't love you.' I mouthed the words and felt my lip tremble.

I turned my high beams back on — a bull kangaroo blinked into the light.

'Shit!' I pulled the wheel sharply, swerving into the oncoming lane. The car's bumper narrowly missed the kangaroo's legs but it turned and leapt-likely blinded by the lights_into my path. A hollow thud reverberated throughout the car as the kangaroo's head smacked against the passenger side window. The tyres screeched, lost purchase on the asphalt and the car fishtailed. I fought the wheel, steadied it and pulled over to the side of the road. When I let go my hands were shaking. I craned my neck upwards but couldn't see anything in the rear-view mirror. I stepped out of the car and circled round to the front, using my phone as a torch. Claw marks were etched at the top left-hand side of the bonnet as though the roo had tried to hang on. There was a white smudge on the window where its head hit. The passenger side mirror was missing. Blood pulsed in my ears as I followed the edge of the road 
away from the car. I scanned the light in front of my feet anticipating a trail of obscene, horror-film blood, but there was nothing. Perhaps the kangaroo survived, and hopped off into the bush? I nearly stumbled over its body.

'Fuck me!' I jumped back and illuminated it with my phone.

It lay on its side - the head and front half of its torso extending onto the road. It would've been well over six-feet upright. Its muscular arms hung limply beneath its head. Nothing was at an odd angle. There was no blood. If not for its blank-eyed stare it might have been sleeping. I took a step forwards and watched its chest-looking for the rise and fall of struggled breath. I circled at a distance, approached its head and crouched to my knees waiting for a twitch from its whiskers, a flare of its nostrils. Nothing.

'Fuck,' I said.

I stood up, too fast, and was struck by a mild dizzy spell. I closed my eyes and it was Tegan beneath me. Naked and unmoving on the road, with the kangaroo's shimmering black-pearl eyes sitting in place of her own, she stared at me. I shook my head and opened my eyes. The kangaroo hadn't moved. I checked up and down the road-no cars had passed but the roo was still part way on the road. I thought about dragging it off - grabbing it by the tail and pulling. But then I wondered what would happen if it wasn't dead. There's nothing as dangerous as a wounded animal. Tegan once told me about a man being sliced clean in two by a kangaroo's claws.

'They're designed to disembowel,' she said.

'But they look so cute and harmless.'

'So do I.' She bared her teeth and scrunched her face into a snarl.

I stepped away from the kangaroo's body. 'I'm so sorry,' I said and made my way back to the car.

I drove once again without purpose. This time headed back north. I caught sight of the aviation tower atop Mount Ainslie and felt like I'd been given some direction.

Early on, Tegan and I would hike often, challenging ourselves to scale as many of the forty odd peaks in the region as we could. In March, by the lake, the city hosts its annual fireworks display. I wanted to avoid 
the crowds in town, so Tegan suggested we make for the mountain. We used our phones to light the way. Halfway up we heard the first explosions. There was a ledge of earth nearby with an unobstructed view of the city. We sat there and watched the sparks whirl, spiral, fizz and tumble above the water's reflective surface.

Once it was over she turned to me in the dark and said, 'To the top then?'

'We've never quit on a summit yet.'

The final climb was a set of stairs that had both of us breathing heavily. At the top, I placed my hands on my knees and caught my breath.

Tegan was standing by the lookout. 'Hey come over here,' she said. 'I want to give you something.'

I walked over grinning, expecting a kiss. Tegan placed a hand on my cheek it was warm and damp. 'Is that it?' I asked.

'Yes. Don't you like it? It's my sweat.' She laughed and ran. I gave chase with mock-fury.

I drove up the mountain this time. Pulled-up at the car park by the summit and walked towards the lookout with Tegan's cackle echoing in my head. The city lights glowed faintly below like a dying candle.

'You'll never catch me!' Tegan laughed.

We ran around the aviation tower like cartoon animals until I gave up, exhausted. 'Truce,' I said between gasps for air.

'Truce,' Tegan agreed, sounding equally ragged.

Once we had caught our breaths we walked over to the lookout. Tegan pressed her waist against the railing, sighed heavily and gazed at those same lights. I came up behind her and kissed her neck, tasting the salty tang of her sweat. I licked my tongue over my lips. She leant back and rested her weight against me.

'Pretty isn't it?' she said.

'Beautiful,' I replied. And then I wrapped my arms around her, knowing that sooner or later we'd have to go back down. 